\title{
EFEKTIVITAS MODEL PROBLEM BASED LEARNING TERHADAP KETERAMPILAN PROSES SAINS SISWA SMA KELAS XI PADA MATERI KESETIMBANGAN KIMIA
}

\author{
Susi $^{1}$, Elvi Yenti ${ }^{2}$ \\ ${ }^{1}$ Program Studi Pendidikan Kimia, Fakultas Tarbiyah dan Keguruan, UIN Suska Riau. \\ Email: susiaripin89@gmail.com \\ ${ }^{2}$ Dosen Program Studi Pendidikan Kimia, FTK, UIN SUSKA Riau \\ Email: elviyenti@uin-suska.ac.id
}

\begin{abstract}
This research was instigated by Chemistry subject at Senior High School of YLPI Pekanbaru that was dominated by discussion, question, and answer methods. These methods did not train student ability in the inquiry, it was proven by the low score of student science process skill on Chemical Equilibrium lesson. This research aimed at knowing the effectiveness of Problem Based Learning model toward student science process skill on Chemical Equilibrium lesson. Quasi-experimental method was used in this research with pretest posttest control group design. The samples were the eleventh-grade students of Natural Science 1 as the experimental group and the students of Natural Science 2 as the control group, and each class had 20 students. Test and observation sheet were the instruments of this research. The data of science process skill test were analyzed by using statistical test and to test the hypothesis was using t-test. The calculation result data of the mean difference of both classes showed that the score of $t_{\text {observed }}$ was 8.66 and table was 1.69 at 0.05 significant level, so $t_{\text {observed }}$ was higher than $t_{\text {table. It showed that Alternative hypothesis was }}$ accepted, it meant that Problem Based Learning model was effective to be used toward student science process skill on Chemical Equilibrium lesson, and the effectiveness percentage score was $75 \%$.
\end{abstract}

Keywords: Problem Based Learning Model, Science Process Skill, Chemical Equilibrium

\section{PENDAHULUAN}

Pendidikan pada dasarnya terdapat proses pembelajaran yang pada hakikatnya berguna untuk mengembangkan keterampilan, aktivitas, dan kreativitas siswa melalui berbagai interaksi dan pengalaman belajar sehingga pembelajaran menjadi lebih bermakna. Suatu proses pembelajaran yang dilaksanakan akan bermakna apabila siswa dapat menemukan sendiri konsep dari materi yang sedang dipelajarinya[1]. Salah satunya dengan pengaplikasikan keterampilan proses sains dalam pembelajaran [2].

Keterampilan proses sains adalah semua kemampuan yang diperlukan untuk memperoleh, mengembangkan, dan menerapkan konsep-konsep, prinsip-prinsip, hukum-hukum dan teori-teori sains baik berupa kemampuan mental, fisik, maupun sosial. Keterampilan proses sains ini penting dimiliki oleh siswa dalam kegiatan inkuiri ilmiah guna menyelesaikan berbagai masalah sains. Menurut Rustaman, keterampilan proses sains meliputi kegiatan melakukan pengamatan, menafsirkan, mengklasifikasi, berkomunikasi, memprediksi, dan merancang percobaan, menerapkan konsep, mengajukan pertanyaan, menggunakan alat, dan menarik kesimpulan[3].

Keterampilan proses merupakan seperangkat keterampilan yang digunakan para ilmuan dalam melakukan penyelidikan [4]. Keterampilan proses merupakan seperangkat keterampilan yang digunakan dalam melakukan penyelidikan untuk menemukan suatu konsep/prinsip/teori. Keterampilan proses IPA dibedakan menjadi dua kelompok yaitu keterampilan proses dasar dan keterampilan proses terintegrasi. Keterampilan proses dasar terdiri atas mengamati, menggolongkan, mengukur, serta mengkomunikasikan, 
menginterpretasi data, memprediksi, menggunakan alat dan bahan, melakukan percobaan, dan menyimpulkan. Keterampilan proses bagian terintegrasi meliputi beberapa keterampilan yaitu keterampilan merumuskan masalah, mengidentifikasi variabel, mendeskripsikan hubungan antarvariabel, mengendalikan variabel, dan mendefinisikan variabel secara operasional, memperoleh dan menyajikan data, dan merumuskan hipotesis, merancang percobaan dan melakukan penyelidikan [5].

Keterampilan proses sains perlu diterapkan kepada siswa, karenaketerampilan proses dapat diartikan sebagai wawasan atau anutan pengembangan keterampilanketerampilan sosial, intelektual, dan fisik yang bersumber dari kemampuan-kemampuan mendasar yang prinsipnya telah ada dalam diri siswa. Keterampilan proses dimaksudkan untuk mengembangkan kemampuan-kemampuan yang dimiliki siswa serta agar siswa dapat menghayati dan memahami pelajaran dengan baik[6]. Keterampilan proses sains penting dalam pembelajaran saat ini, karena perkembangan ilmu pengetahuan dan teknologi berlangsung semakin cepat sehingga guru tidak hanya mengajarkan semua konsep dan fakta kepada siswa, adanya kecenderungan bahwa siswa lebih memahami konsep-konsep yang rumit dan abstrak jika disertai dengan contoh yang konkret, penemuan dan perkembangan ilmu pengetahuan dan teknologi, tidak bersifat mutlak, tetapi bersifat relative, dalam proses belajar mengajar, pengembangan konsep tidak terlepas dari pengembangan sikap dan nilai dalam diri siswa[7].

Penyebab yang menjadikan beberapa aspek keterampilan proses sains belum terpenuhi diantaranya adalah pembelajaran yang digunakan belum menerapkan dan mengoptimalkan aspek-aspek yang ada pada keterampilan proses sains siswa, meskipun sudah dilakukan usaha untuk mengajak siswau ntuk terlibat kedalam proses pembelajaran, dari siswa itu sendiri masih ditemukan kegiatankegiatan yang tidak termasuk dalam pembelajaran seperti mengobrol dengan teman dan beberapa siswa mengerjakan tugas dari pelajaran lain saat pembelajaran berlangsung. Sehingga perlu segera diatasi agar proses pembelajaran dapat terlaksana dengan baik[8].

Fakta yang terjadi di lapangan, pembelajaran sains masih terbilang belum menyentuh pengembangan keterampilan proses sains secara optimal. Penelitian Suastra dalam Yuyu Yuliati menjelaskan bahwa rendahnya pembelajaran sains disebabkan karena tolak ukur keberhasilan pendidikan disekolah masih difokuskan pada segi konsep. Pembelajaran sains selama ini memiliki kecenderungan hanya mengasah aspek mengingat, dan memahami, kurang melatih keterampilan siswa dalam berinkuiri. Keadaan ini diperparah dengan kondisi dimana fokus penyajian pembelajaran hanya dilakukan dengan kegiatan ceramah sehingga mengakibatkan kegiatan siswa ketika belajar sangat terbatas. Hal ini didukung oleh penelitian pusat kurikulum Departemen Pendidikan Nasional tahun 2007 yang menyatakan bahwa metode ceramah dengan cara menulis dipapantulis merupakan metode yang paling banyak digunakan[9].

Berbagai temuan tersebut, juga didukung oleh hasil studi pendahuluan dari peneliti di SMA YLPI Pekanbaru, bahwa saat pembelajaran berlangsung, guru cenderung menggunakan metode ceramah/teacher center, dan kurangnya pelaksanaan peraktikum.

Berdasarkan hasil studi pendahuluan yang sudah dilakukan, keterampilan proses sains siswa masih tergolong rendah. Dalam hal ini ada beberapa indikator keterampilan proses sains yang sangat perlu dan penting untuk diamati dalam proses pembelajaran, yaitu indikator mengamati, menafsirkan, meramal, menerapkan konsep, merencanakan percobaan, menggunakan alat dan bahan, berkomunikasi, dan mengajukan pertanyaan. Selama proses pembelajaran berlangsung indikator-indikator tersebut semua sudah dimiliki siswa, namun masih 20\%. Indikator-indikator tersebut sulit didapatkan tiap siswa karena dalam belajar guru hanya meberikan penjelasan dari awal hingga akhir pembelajaran tanpa memberikan siswa peluang untuk terjun langsung kelapangan seperti praktikum. Maka dari itu siswa cenderung pasif, tidak aktif dalam bertanya dan lainnya karena semuanya tidak 
dibuktikan secara nyata hanya sekedar bayangan.

Berbagai upaya selayaknya dilakukan pelaksanaan pembelajaran sains yang memiliki tujuan untuk membenahi pembelajaran yang bermuara pada peningkatan mutu proses dan hasil pembelajaran sehingga pada akhirnya dapat mempersiapkan siswa di masa depan. Salah satu alternatif proses pembelajaran yang memberikan peluang siswa untuk memiliki keterampilan proses sains adalah model pembelajaran. Dalam hal ini akan dilihat efektifitas dari model pembelajaran tersebut.

Salah satu model pembelajaran yang dapat digunakan adalah model problem based learning. Problem based learning adalah suatu pendekatan pembelajaran yang menggunakan masalah sebagai titik tolak pembelajaran dan untuk dapat menyelesaikan suatu masalah peserta didik memerlukan pengetahuan baru untuk dapat menyelesaikannya[10]. Menurut Arends, model tersebut merupakan pembelajaran yang berorientasi pada masalah dan pemecahannya didalam kelas. Ciri utama model pembelajaran ini adalah bahwa pengetahuan dicari dan dibentuk oleh siswa dalam upaya memecahkan contoh-contoh masalah yang dihadapkan pada mereka[11].

Tujuan penelitian ini adalah untuk untuk mengetahui keefektifan model Problem Based Learning terhadap keterampilan proses sains siswa kelas XI pada materi kesetimbangan kimia.

\section{METODE PENELITIAN}

Penelitian yang dilakukan merupakan penelitian kuantitatif dengan menggunakan metode eksperimen semu (quasi eksperimental). Tujuan dari penelitian eksperimen semu ini adalah untuk memperoleh informasi yang menjadi perkiraan bagi informasi yang dapat diperoleh dengan eksperimen murni dalam keadaan yang tidak memungkinkan untuk mengontrol semua variabel yang relevan[12].

Desain yang digunakan peneliti adalah Nonequivalent Control Group Design. Penelitian ini menggunakan dua kelompok sampel. Kelompok pertama diberi perlakuan/treatment $(\mathrm{X})$ dan kelompok kedua tidak diberi perlakuan. Kelompok yang diberi perlakuan disebut kelompok eksperimen dan kelompok yang tidak diberi perlakuan disebut kelompok kontrol. Desain ini hampir mirip dengan pretest posttest controlgroup design, hanya saja pada desain ini kelompok ekspermen dan kelompok kontrol tidak dipilih secara random (acak)[13]. Secara rinci desain Nonequivalent Control Group Design dapat dilihat pada tabel berikut[14]:

Tabel.1 Desain Penelitian

Nonequivalent Control Group Design

\begin{tabular}{|c|c|c|c|}
\hline Kelompok & Pretest & $\begin{array}{c}\text { Perlakua } \\
\text { n }\end{array}$ & Posttest \\
\hline $\mathrm{K}_{\mathrm{E}}$ & $\mathrm{O}_{1}$ & $\mathrm{X}$ & $\mathrm{O}_{2}$ \\
\hline $\mathrm{K}_{\mathrm{K}}$ & $\mathrm{O}_{1}$ & $\ldots .$. & $\mathrm{O}_{2}$ \\
\hline
\end{tabular}

Waktu dan Tempat Penelitian

Penelitian ini dilaksanakan di SMA YLPI Pekanbaru pada kelas XI semester genap pada bulan januari tahun 2019-februari tahun 2020.

Subjek dan Objek Penelitian

Subjeknya dalam penelitian ini adalah peserta didik kelas XI di SMA YLPI Pekanbaru. Sedangkan objek dalam penelitian ini adalah keterampilan proses sains siswa dengan menggunakan model pembelajaran Problem Based Learning pada mata pelajaran kimia SMA pada materi kesetimbangan kimia.

Populasi pada penelitian ini adalah seluruh siswa kelas XI IPA yang siswanya berjumlah 60 orang di SMA YLPI Pekanbaru Tahun Pelajaran 2019/2020. Sampel adalah bagian dari populasi (sebagian atau wakil populasi) yang diteliti[15]. Pada penelitian ini yang ditetapkan sebagai sampel adalah sampel adalah siswa kelas XI IPA 1 sebagai kelas eksperimen dan XI IPA 2 sebagai kelas kontrol yang masing-masing kelas terdiri dari 20 orang siswa.

Teknik Pengumpulan Data

Teknik pengumpulan data pada penelitian ini yaitu lembar observasi, dokumentasi, dan tes. Instrumen yang digunakan untuk tes adalah soal uraian. 
Pengamatan atau observasi adalah suatu teknik yang dilakukan dengan cara mengadakan pengamatan secara teliti serta pencatatan secara sistematis[16]. Observasi yang dilakukan dalam penelitian ini adalah observasi langsung, yang mengumpulkan data berdasarkan pengamatan yang menggunakan mata atau telinga secara langsung. Dengan demikian, melalui observasi yang dilakukan ini dapat terlihat kemunculan keterampilan proses sains siswa yang di amati secara langsung oleh panca indera. Pada penelitian ini ada beberapa indikator keterampilan proses sains yang diteiti, diantaranya: indikator keterampilan mengamati, menafsirkan, meramal, merencanakan percobaan, menggunakan alat dan bahan, menerapkan konsep, berkomunikasi, dan mengajukan pertanyaan. Adapun indikator yang akan diamati dalam penelitian ini adalah indikator mengamati (observasi), menafsirkan, meramal (prediksi), menerapkan konsep, merencanakan percobaan, menggunakan alat dan bahan, berkomunikasi dan mengajukan pertanyaan.

Dalam hal ini, dilakukan dokumentasi untuk memperoleh daftar nama dan jumlah siswa kelas XI SMA YLPI Pekanbaru, Rancangan Pelaksanaan Pembelajaran (RPP), serta mendokumentasikan aktivitas siswa saat pembelajaran berlangsung. Dokumentasi ini ditujukan untuk memperoleh data secara langsung dari tempat penelitian yang meliputi buku yang relevan, laporan kegiatan, foto-foto dan data yang relevan dengan penelitian yang dilakukan. Foto dokumentasi berfungsi sebagai alat perekam kegiatan pembelajaran yang berlangsung. Hasil lembar pengamatan digunakan sebagai bukti nyata dari pengumpulan data tentang keterampilan proses sains siswa. RPP digunakan sebagai bukti dari rancangan proses pembelajaran yang digunakan selama proses pembelajaran.

Teknik pengumpulan data melalui tes ini dapat berupa beberapa soal essay yang akan diberikan kepada responden untuk di jawab sebelum dan setelah melakukan pembelajaran dengan menggunakan model pembelajaran Problem Based Learning. Tes ini dilakukan kepada kedua kelas yang akan di uji coba yaitu kelas ekperimen dan kelas kontrol. Dimana tujuan dilakukannya tes ini supaya bisa terlihat keefektifan penggunaan model problem based learning antara kelas eksperimen (menggunakan model Problem Based Learning) dengan kelas kontrol (tanpa model Problem Based Learning).

\section{Teknik Analisis Data}

Teknik analisis data pada penelitian ini adalah teknik analisis data kualitatif dan kuantitatif. Penilaian observasi menggunakan alat atau instrument berupa lembar observasi dengan daftar ceklis dan skala penilaian. Teknik analisis data berupa analisis data yang digunakan untuk mengetahui gambaran keterampilan proses sains pada saat proses pembelajaran berlangsung. Data keterampilan proses sains dihitung menggunakan rumus sebagai berikut:

$$
\text { Nilai }=\frac{\text { skor yang diperoleh }}{\text { skor maksimal }} \times 100 \%
$$

Tabel.2 Kriteria Skor Penilaian

\begin{tabular}{ll}
\hline Persentase $(\%)$ & Keterangan \\
\hline $81-100$ & Sangat Baik \\
$61-80$ & Baik \\
$41-60$ & Cukup \\
$21-40$ & Kurang \\
$0-20$ & Sangat Kurang \\
\hline
\end{tabular}

Analisis data penelitian, terdiri atas analisis data awal (uji homogenitas), uji normalitas, dan analisis data akhir (uji hipotesis) serta penentuan nilai efektivitas dari penggunaan model pembelajaran.

Sebelum menganalisis data dengan test " $t$ ", maka data yang didapat harus dilakukan uji normalitas terlebih dahulu, uji ini bertujuan untukmenguji apakah suatu sampel dalam penelitian ini berasal dari populasi yang normal atau tidak. Untuk menguji normalitasnya dapat menggunakan Chi kuadrat,maka rumus yang digunakan adalah[17]:

$$
\chi^{2}=\frac{\sum\left(f_{0}-f_{h}\right)^{2}}{f_{h}}
$$

Analisis data akhir meliputi uji prasyarat (uji homogenitas dan uji normalitas) 
dan uji hipotesis dengan menggunakan test " $\mathrm{t}$ ". untuk menentukan efektivitas dari penggunaan model problem based learning digunakan rumus[18]:

$$
P=\frac{F}{N} \times 100 \%
$$

Tabel.3 kriteria efektivitas

\begin{tabular}{ll}
\hline Persentase & Keterangan \\
\hline $1 \%-24 \%$ & Tidak Efektif \\
$25 \%-49 \%$ & Kurang Efektif \\
$50 \%-74 \%$ & Kurang Efektif \\
$75 \%-100 \%$ & Efektif \\
\hline
\end{tabular}

\section{HASIL DAN PEMBAHASAN}

Data hasil penelitian ini berupa keterampilan proses sains siswa pada materi kesetimbangan kimia. Pengukuran keterampilan proses sains siswa menggunakan lembar observasi. Data hasil penelitian tersebut diperoleh dari dua kelas sampel yang merupakan bagian dari populasi kelas XI SMA YLPI Pekanbaru. Kelas XI IPA 1 sebagai kelas eksperimen dan kelas XI IPA 2 sebagai kelas kontrol, masing-masing kelas terdiri dari 20 orang siswa. Kelas kontrol menggunakan metode konvensional, sedangkan kelas eksperimen menggunakan model problem based learning.pembelajaran dilakukan sebanyak 3 kali pertemuan. Materi pembelajaran IPA kimia tentang kesetimbangan kimia.

Observasi pada penelitian ini menggunakan observasi guru dan observasi keterampilan proses sains siswa. Observasi guru bertujuan untuk mengetahui keterlaksanaan dan kesesuaian Rencana pelaksanaan Pembelajaran (RPP) dengan langkah-langkah pembelajaran yang dilakukan oleh peneliti. Sedangkan obervasi keterampilan proses sains siswa digunakan untuk mengetahui perilaku siswa yang berkaitan dengan keterampilan proses sains selama proses pembelajaran berlangsung.

Observasi dilakukan menggunakan lembar observasi yang sudah divalidasi oleh dosen pembimbing ibu Elvi Yenti, S.Pd., M.Si. analisis uji validitas dilakuan uji validitas isi oleh ahlinya dengan melihat kesesuaian antara indikator dengan pernyataan, serta kesesuaian bahasa yang digunakan.

Observer dalam penelitian ini berjumlah 2 orang observer yang bertugas untuk mengamati kegiatan siswa dalam proses pembelajaran. Masing-masing observer mengamati 3 kelompok secara bergantian. Mereka melakukan penilaian menggunakan lembar observasi keterampilan proses sains siswa dengan daftar ceklis dan skala penilaian yang terdapat dalam lembar observasi tersebut. Nilai keterampilan proses sains siswa antara kelompok eksperimen dengan kelompok kontrol dianalisis dengan menggunakan uji t. uji t digunakan untuk melihat ada tidaknya perbedaan yang signifikan antara kelas eksperimen dan kelas kontrol. Berdasarkan analisis tersebut dapat diketahui efektivitas dari penggunaan model problem based learning terhadap keterampilan proses sains.

Berikut disajikan perolehan nilai dari rata-rata kelas eksperimen dan kelas kontrol.

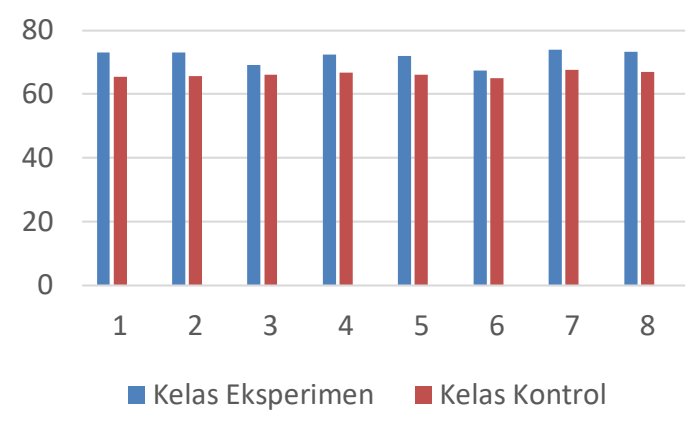

Gambar.1 Grafik Persentase nilai Keterampilan Proses Sains Siswa Kelas Eksperimen dan Kelas Kontrol

Gambar tersebut menunjukkan perolehan nilai keterampilan proses sains masing-masing siswa pada materi kesetimbangan kimia pada kelas eksperimen dengan model problem based learning lebih tinggi daripada kelas kontrol yang menggunakan metode konvensional. Indikator pada grafik tersebut untuk nomor 1 ialah indikator mengamati, nomor 2 indikator meramal, nomor 3 menafsirkan, nomor 4 menggunakan alat dan bahan, nomor 5 berkomunikasi, nomor 6 menerapkan konsep, nomor 7 merencanakan percobaan, dan nomor 8 mengajukan pertanyaan. Dari kedelapan 
indikator keterampilan proses sains siswa, keterampilan merencanakan percobaan memperoleh persentase yang tinggi yaitu $74 \%$, sedangkan indikator yang memiliki persentase terendah adalah keterampilan menerapkan konsep dengan nilai persentase 67,3\%.

Data keterampilan proses sains siswa dianalisis secara statistic menggunakan uji-t untuk mengetahui pengaruh model problem based learning terhadap keterampilan proses sains siswa. Rancangan hipotesis untuk keputusan uji adalah:

Ho : Tidak terdapat perbedaan rata-rata nilai keterampilan proses sains antara kelas eksperimen dan kelas kontrol.

$\mathrm{Ha}$ : Terdapat perbedaan rata-rata nilai keterampilan proses sains antara kelas eksperimen dan kelas kontrol.

Berikut disajikan hasil analisis:

Tabel.4 Hasil Analisis uji-t pengaruh model problem based learning terhadap keterampilan proses sains siswa.

\begin{tabular}{c|c|c|c|c|c}
\hline Kelas & $\mathbf{N}$ & $\sum \mathbf{X}$ & $\overline{\boldsymbol{X}}$ & $\mathbf{t}_{\text {hitung }}$ & $\mathbf{t}_{\text {tabel }}$ \\
\hline $\begin{array}{c}\text { Eksperi } \\
\text { men }\end{array}$ & 20 & 339 & 16,95 & 8,66 & 1, \\
\hline Kontrol & 20 & 209 & 10,45 & & 69 \\
\hline
\end{tabular}

Keterampilan proses sains pada indikator merencanakan percobaan memiliki nilai persentase yang tertinggi dibandingkan indikator-indikator yang lain dikarenakan pada indikator ini siswa lebih cenderung menyukai sesuatu yang bersifat nyata seperti praktek langsung. Pada indikator merencanakan percobaan mereka bisa secara langsung meatih kemampuan dengan diakukan praktikum. Sedangkan nilai persentase terendah yaitu pada indikator menerapkan konsep. Persentasenya rendah karena pada indikator ini mereka sering mengalami kendala-kendala dibagian teori dikarenakan pada materi kesetimbangan kimia banyak konsep-konsep yang belum mereka pahami. Mereka lebih menyukai praktek langsung dibandingkan dengan teori saja tanpa adanya bukti nyata.

Keterampilan proses sains penting untuk dimiliki setiap individu dalam proses pembelajaran, dimana keterampilan proses sains ini akan menggali kemauan siswa dan membuat siswa lebih aktif, dan membantu siswa untuk melakukan aktivitas pembelajaran dengan mendapatkan bukti-bukti nyata.

\section{Pengaruh Model Problem Based learning terhadap keterampilan Proses Sains}

Aspek keterampilan proses sains yang diukur meliputi aspek mengamati, menggunakan alat dan bahan, memprediksi, meramal, merencanakan percobaan, menerapkan konsep, berkomunikasi dan mengajukan pertanyaan. Nilai kelas eksperimen dari kedelapan aspek tersebut lebih tinggi daripada kelas kontrol. Hal tersebut dikarenakan penggunaan model problem based learning di kelas eksperimen.

Indikator pertama adalah mengamati, terlihat pada gambar 1 bahwa siswa kelas eksperimen lebih unggul daripada kelas control, hal ini dikarenakan siswa kelas eksperimen yang diterapkan pembelajarn problem based learning terlebih dahulu diberikan suatu permasalahan yang berkaitan dengan materi, dari pemberian masalah tersebut akan muncul pertanyaan 'mengapa' dalam diri siswa yang memunculkan rasa penasaran dari permasalahan yang di hadapinya tersebut. Sehingga siswa akan mengamati dengan lebih seksama dan didapatkan beberapa data awal dari permasalahan tersebut. Dengan demikian, pembelajaran dengan model problem based learning dapat meningkatkan keterampilan proses sains siswa pada aspek mengamati. Penelitian oleh Aan Hanafiah juga mengungkapkan bahwa pada proses pembelajaran dengan model problem based learning siswa dihadapkan dengan wacanawacana yang diawali dengan masalah, sehingga dapat membantu siswa untuk lebih terampil dalam menghadapi suatu peristiwa[19].

Indikator kedua adalah keterampilan meramal, terlihat pada gambar 1 yang sudah disajikan bahwa keterampilan meramalkan siswa kelas eksperimen lebih unggul dari kelas kontrol, hal ini dikarenakan siswa kelas eksperimen yang diterapkan pembelajarn problem based learning diberikan lembar masalah sehingga siswa akan menerka 
kemungkinan hasil yang akan diperoleh dari suatu praktikum dan siswa akan meramalkan suatu keadaan tertentu yang belum pernah diamati secara langsung dengan didasarkan pada pengetahuan yang sudah diperoleh. Dengan demikian keterampilan proses sains siswa pada aspekmeramalkan dapat dikuasai dengan baik oleh siswa.

Indikator ketiga adalah keterampilan menafsirkan, terlihat pada gambar 1 bahwa siswa kelas eksperimen lebih unggul daripada kelas kontrol, hal ini dikarenakan siswa kelas eksperimen yang diterapkan pembelajaran problem based learning terlebih dahulu diberikan suatu permasalahan dalam melakukan praktrikum atau percobaan sehingga siswa memperoleh informasi awal dari praktikum. Informasi awal yang diperoleh akan mempermudah siswa untuk menafsirkan konsep apa yang berhubungan dengan masalah tersebut sesuai dengan pemahaman atau informasi yang telah diketahui sebelumnya. Dengan demikian, dapat membantu siswa agar lebih terampil dalam menafsirkan peristiwa yang terjadi dan terbukti bahwa penggunaan model problem based learning ini dapat meningkatkan keterampilan proses sains siswa pada aspek menafsirkan, dan keterampilan proses sains siswa pada aspek menafsirkan akan semakin berkembang.

Indikator keempat adalah indikator keterampilan menggunakan alat dan bahan, terlihat pada gambar 1 bahwa siswa kelas eksperimen lebih unggul daripada kelas kontrol, hal ini dikarenakan siswa kelas eksperimen yang diterapkan pembelajaran dengan menggunakan problem based learning tidakhanya merancang percobaan, tetapi siswa kelas eksperimen ini juga dituntut untuk menentukan alat dan bahan yang sesuai dengan percobaan yang siswa rancang secara berkelompok sehingga siswa lebih mengetahui tujuan dan cara menggunakan alat tersebut. Dengan demikian pembelajaran dengan model problem based learning ini dapat meningkatkan keterampilan proses sians siswa pada aspek menggunakan alat dan bahan. Donnel at al menyatakan bahwa pergeseran tanggungjawab untuk menyusun prosedur praktikum kesiswa berarti siswa harus menyadari apakah percobaan tersebut yang mereka rancang itu cocok, mengapa harus seperti itu, dan apa yang akan terjadi.

Indikator kelima adalah keterampilan berkomunikasi, terlihat pada gambar 1 yang sudah disajikan bahwa keterampilan berkomunikasi siswa kelas eksperimen lebih unggul dari kelas kontrol, hal ini dikarenakan siswa kelas eksperimen yang diterapkan pembelajarn problem based learning diberikan wacana-wacana yang membuat siswa aktif dalam proses belajar mengajar, dilakukan dengan cxara diskusi kelompok dan mempersentasekan hasil karyanya di depan kelas dan kelompok lain, sehingga komunikasi antara guru dengan siswa terlaksana dengan baik. Dengan demikian model problem based learning ini dapat meningkatkan keterampilan proses sains siswa pada aspek berkomunikasi dan keterampilan berkomunikasi-nya semakin berkembang[20].

Indikator keenam adalah keterampilan menerapkan konsep, terlihat pada gambar 1 yang sudah disajikan bahwa keterampilan menerapkan konsep siswa kelas eksperimen lebih unggul dari kelas kontrol, hal ini dikarenakan siswa kelas eksperimen yang diterapkan model problem based learning diberikan suatu contoh dari peristiwa yang terjadi sehingga siswa bisa menerapkan konsep yang telah dipelajari pada keadaan baru. Dengan demikian model problem based learning ini dapat meningkatkan keterampilan proses sains siswa pada aspek menerapkan konsep.

Indikator ketujuh adalah keterampilan merencanakan percobaan, terlihat pada gambar 1 yang sudah disajikan bahwa keterampilan merencanakan percobaan siswa kelas eksperimen lebih unggul dari kelas kontrol, hal ini dikarenakan siswa kelas eksperimen yang diterapkan model problem based learning terlebih dahulu diberikan suatu permasalahan yang berbentuk gambar atau video yang dapat membantu siswa agar lebih terampil dalam merencanakan percobaan. Dengan demikian model problem based learning ini dapat meningkatkan keterampilan proses sains siswa pada aspek merencanakan percobaan. 
JEDCHEM (Journal Education and Chemistry)

Vol. 2 No. 2 Juni 2020

Indikator kedelapan adalah keterampilan mengajukan pertanyaan, terlihat pada gambar 1 yang sudah disajikan bahwa keterampilan mengajukan pertanyaan siswa kelas eksperimen lebih unggul dari kelas kontrol, , hal ini dikarenakan siswa kelas eksperimen yang diterapkan model problem based learning diberikan permasalahan yang dapat memunculkan pertanyan-pertanyaan siswa berkaitan dengan materi pembelajaran. Dengan demikian model problem based learning ini dapat meningkatkan keterampilan proses sains siswa pada aspek mengajukan pertanyaan.

Berdasarkan rata-rata keterampilan proses sains siswa dalam tiga kali pertemuan sesuai dengan gambar 1 yang telah disajikan diperoleh hasil untuk kelas eksperimen memiliki skor keterampilan proses sains siswa lebih unggul daripada kelas kontrol, dan uji hipotesis yang dilakukan menggunakan uji $\mathrm{t}$ diperoleh nilai $t_{\text {hitung }}>t_{\text {tabel }},(8,66>1,69)$ pada taraf signifikan $5 \%$. Dengan demikian setelah diketahui bahwa model yang digunakan efektif terhadap keterampilan proses sains siswa dilakukan perhitungan untuk mengetahui besarnya persentase efektivitasnya. Perhitungan dilakukan dengan menggunakan uji efektivitas, dan diperoleh besarnya persentasi efektivitas penggunaan model problem based learning terhadap keterampilan proses sains siswa adalah sebesar $75 \%$.

\section{SIMPULAN DAN SARAN}

Simpulan

Berdasarkan hasil penelitian yang dilakukan, dapat disimpulkan bahwa model pembelajaran problem based learning lebih efektif digunakan dibandingkan dengan model konvensional terhadap keterampilan proses sains siswa pada materi kesetimbangan kimia. Hal tersebut dapat dilihat dari nilai persentase yang diperoleh untuk efektivitas model yang digunakan dengan nilai $75 \%$ dan diperoleh nilai $t_{\text {hitung }}>t_{\text {tabel }}$, dimana nilai $t_{\text {hitung }}=8,66$ sedangkan nilai $\mathrm{t}_{\text {tabel }}$ pada taraf signifikan $5 \%=1,69$.
Saran

Peneliti selanjutnya diharapkan bisa lebih efisien dalam menggunakan model pembelajaran yang bervariasi, agar model yang digunakan sesuai dengan materi pembelajaran yang akan dipelajari, serta dapat memperkaya ilmu pengetahuan di bidang pendidikan.

Bagi peneliti yang akan melakukan penelitian efektivitas model pembelajaran diharapkan lebih mempersiapkan segala sesuatu dengan sangat baik terutama dalam memilih sekolah yang akan diteliti.

Bagi peneliti selanjutnya diharapkan lebih banyak menggunakan sumber-sumber lain seperti buku, jurnal dan sejenisnya.

\section{REFERENSI}

[1] Damopoli, I. (2018). Meningkatkan Keterampilan Proses Sains dan Hasil Belajar Siswa Melalui Pembelajaran berbasis Inkuiri. Jurnal Bioedukatika, 6, 22-30

[2] Mely Cholifatul Janah, A. T. (2018). Pengaruh Model Problem Based Learning Terhadap Hasil Belajar dan Keterampilan Proses Sains. Jurnal Inovasi Pendidikan Kimia, 12, 2097-2107.

[3],[9] Yulianti, Y. (2016). Peningkatan keterampilan Proses Sains Siswa Sekolah Dasar Melalui Model pembelajaran berbasis Masalah. Jurnal Cakrawala Pendas, 2, 71-83.

[4] Qomariyah. (2014). Penerapan Model Pembelajaran Guided Discovery untuk Meningkatkan Keterampilan Proses Sains Siswa Kelas VII. Jurnal Pendidikan Sains e-Pensa, 02, 01, 78-88.

[5] Kementerian Pendidikan dan Kebudayaan. (2013). Buku Guru Ilmu Pengetahuan Alam SMP/MTs Kelas VIII. Jakarta: Kementerian Pendidikan dan Kebudayaan. 
JEDCHEM (Journal Education and Chemistry)

Vol. 2 No. 2 Juni 2020

[6], [7] Kurnia, S. (2015). Pengaruh Model Pembelajaran Problem Based Learning Terhadap Keterampilan Proses Sains Menyimpulkan Hasil Percobaan Siswa pada Pembelajaran Fisika Dikelas X SMA Negeri 1 Tanjung Lubuk. Jurnal Inovasi dan Pembelajaran Fisika. ISSN: 22489010.

[8] Andi, W. (2015). Pengaruh Problem Based Learning dengan Konsep Awal Terhadap Keterampilan Proses Sains dan Hasil Belajar Biologi Siswa Kelas X SMA Negeri Jumpolo Tahun 2013/2014. Jurnal Pendidikan Kimia. ISSN: 2252-6897.

[10] Purba, F. J. (2015). Pengaruh Model Problem Based Learning dengan Pemahaman konsep awal terhadap Keterampilan Proses sains Siswa SMA. Jurnal Pendidikan Fisika, 4, 8-13.

[11] Hasanah, A. (2017). Pengaruh Penerapan Model Problem Based Learning terhadap Keterampilan Proses Sains Siswa. Jurnal Pendidikan Sains, 5, 56-64.

[12] Suryabata, S. (2015). Metodologi Penelitian. Jakarta: Rajawali Pers.

[13],[14] Emzir. (2017). Metodologi Penelitian Pendidikan Kuantitatif dan Kualitatif. Depok: Rajawali Press.
[15] Riduwan. (2009). Belajar Mudah Penelitian untuk Guru, Karyawan dan pemula. Bandung: Alfabeta.

[16] Arikunto, S. (2005). Dasar-Dasar Evaluasi Pendidikan. Jakarta: Bumi Aksara.

[17] Hartono. (2012). Statistik untuk Penelitian. Yogyakarta: Pustaka Belajar.

[18] Daud, M. (2018). Efektivitas Pembelajaran Keterampilan Proses Sains pada Pokok Bahasan Termokimia dalam Meningkatkan Kemampuan Siswa di SMAN 1 Krueng Barona Jaya Kabupaten Aceh Besar Dinas Pendidikan Aceh. Jurnal Lantanida, 6, 90-102.

[19] Aan, H. (2015). Pengaruh Model Problem Based Learning (PBL) terhadap Keterampilan Proses Sains (KPS) Siswa pada Materi Laju Reaksi, Skripsi. Universitas Islam Negeri Sultan Syarif Hidayatullah.

[20] Indah, P.R. (2012). Inovasi Pembelajaran Berbasis Masalah Berbantuan Media Transvisi untuk Meningkatkan Keterampilan Proses Sains. Jurnal FMIPA Universitas Negeri Semarang. ISSN: 1504-9876. 